\title{
Standing To Object to an Unreasonable Search and Seizure
}

Although evidence obtained by an unconstitutional search and seizure may not be used at trial against the "victim"1 of the search," other persons who do not have "standing"3 to object to the search can be convicted on the basis of the same evidence. Frequently, an illegal search will turn up incriminating evidence against both the victim and his accomplices. 4 Under the present rule the victim, often the ringleader, ${ }^{5}$ goes free because his constitutional rights were invaded by the police, while his partners in crime go to prision. Another recurring situation is that in which the perpetrator of the crime hides incriminating evidence, generally a weapon or stolen goods, in the home of a friend or relative. ${ }^{6}$ If the evidence is found, it may be admitted against the perpetrator, no matter how flagrantly the friend's or relative's privacy may have been invaded in the process.

The problem of standing in search and seizure cases has occupied the attention of courts and commentators for years. ${ }^{7}$ While many

1 As used here, a "victim" is "one against whom the search was directed, as distinguished from one who claims prejudice only through the use of evidence gathered as a consequence of a search or seizure directed at someone else." Jones v. United States, 362 U.S. 257, 261 (1960).

2 This exclusionary rule was first adopted by the federal system in Weeks v. United States, 232 U.S. 383 (1914), and applied to the states through the fourteenth amendment in Mapp v. Ohio, 367 U.S. 643 (1961).

3 The term "standing" is sometimes used to refer only to a person's right to invoke the judicial process on his behalf. Here, however, it is meant to include also the right of a party already engaged in litigation to make certain contentions. Standards in the former situation are sometimes stricter. See generally 3 Davis, Administrartve LAw $\S 22.07$ (1958).

4 E.g., Wong Sun v. United States, 371 U.S. 471 (1963); Hair v. United States, 289 F.2d 894 (D.C. Cir. 1961); Huffmeister v. State, 170 Tex. Crim. 460, 341 S.W.2d 928 (1960).

5 See Comment, Judicial Control of Illegal Search and Seizure, 58 YALE L.J. 144, 157 (1948).

6 E.g., Combs v. Commonwealth, 341 S.W.2d 774 (Ky. Ct. App. 1960); Fondren v. State, 253 Miss. 241, 175 So. 2d 628 (1965); State v. Anderson, 384 S.W.2d 591 (Mo. Sup. Ct. 1964); Sanders v. State, 351 P.2d 1079 (Okla. Ct. Cr. App. 1960); Commonwealth v. Raymond, 412 Pa. 194, 194 A.2d 150 (1963), cert. denied, 377 U.S. 999 (1964); White v. State, 362 S.W.2d 650 (Tex. Ct. Crim. App. 1962).

7 Soon after the exclusionary rule was adopted in the federal court system, the standing issue became a frequent source of dispute. See, e.g., Goldberg v. United States, 297 Fed. 98 (5th Cir. 1924); Lusco v. United States, 287 Fed. 69 (2d Cir. 1923); Chicco v. United States, 284 Fed. 434 (4th Cir. 1922). Likewise, those states that adopted the exclusionary 
commentators have called for the simple expedient of suppressing all evidence obtained by unreasonable searches and seizures without regard to whether the defendant's personal privacy was invaded, ${ }^{8}$ the courts have almost unanimously rejected the suggestion. ${ }^{9}$ The Supreme Court has twice declared that a defendant cannot object to an unreasonable search and seizure unless he can show a personal interest in either the property seized or the premises searched.10

Two recent developments in search and seizure law make a reexamination of the standing issue particularly appropriate. The decision in Mapp v. Ohio, ${ }^{11}$ requiring the states to observe the exclusionary rule, has made standing an important issue in all fifty state systems of criminal justice. Those states that had rejected the exclusionary rule before it was found to be a constitutional requirement have now been forced to develop rather intricate standards surrounding a rule for which they share no enthusiasm. In addition, a major doctrinal development may have taken place as a result of the Court's opinion in Linkletter $v$. Walker ${ }^{12}$ denying retroactive effect to the Mapp decision. Whereas in the past there had been some confusion as to whether the exclusionary rule was an outgrowth of the privilege against selfincrimination or a general deterrence mechanism to control police misbehavior, the Court in Linkletter appears to have committed itself rather firmly to the deterrence rationale.

This comment examines the premises upon which the Supreme Court formulated its personal interest requirement for standing in search and seizure cases. Then it discusses the implications the Link-

rule before Mapp were called upon to develop criteria for standing. See, e.g., Anderson v. Commonwealth, 204 Ky. 486, 264 S.w. 1087 (1924); Lee v. City of Oxford, 134 Miss. 647, 99 So. 509 (1924); State v. Fenley, 309 Mo. 534, 275 S.W. 41 (1925). Commentators have been wrestling with the problem since 1941. See Grant, Circumventing the Fourth Amendment, 14 So. CaL. L. Rev. 359, 368 (1941).

8 Allen, The Wolf Case: Search and Seizure, Federalism, and the Civil Liberties, 45 Int. L. REv. 1, 22 (1950); Broeder, Wong Sun v. United States: $A$ Study in Faith and Hope, 42 NEB. L. REv. 483, 540 (1963); Grant, supra note 7, at 368; Traynor, Mapp v. Ohio at Large in the Fifty States, 1962 Duke L.J. 319, 335 (1962); Comment, Standing to Object to an Unlawful Search and Seizure, 1965 Wash. U.L.Q. 488; Comment, supra note 5, 58 YALE L.J. 144, 157 (1948). But see Edwards, Standing to Suppress Unreasonably Seized Evidence, 47 Nw. U.L. REv. 471, 472 (1952); Weeks, Standing to Object in the Field of Search and Seizure, 6 ARIz. L. REv. 65 (1964); Comment, Standing to Suppress Evidence Obtained by Unconstitutional Search and Seizure, 55 MrcH. L. Rev. 567, 581 (1957).

9 The lone dissenter is the California Supreme Court. See text accompanying notes 81-84 infra.

10 Wong Sun v. United States, 371 U.S. 471, 492 (1963); Jones v. United States, 362 U.S. 257, 261 (1960).

11367 U.S. 643 (1961).

12381 U.S. 618 (1965). 
letter deterrence rationale may have for the standing requirement. Finally, it determines whether the abandonment of the personal interest requirement in favor of a rule that any defendant may object to any unconstitutional search and seizure can be reconciled with general constitutional notions of standing.

\section{The Personal Interest Requirement FOR STANDING: Jones AND Wong Sun}

Jones $v$. United States ${ }^{13}$ represents the Supreme Court's only full discussion of the standing issue in a search and seizure case. ${ }^{14}$ Narcotics were found hidden in the awning of a friend's apartment in which the defendant and five others were gathered. ${ }^{15}$ The friend was out of town and had given Jones permission to use the apartment during his absence. Jones paid nothing for the privilege, had a key to the apartment, kept some clothes there, and had slept there "maybe a night." When the narcotics were found, Jones disclaimed ownership of them. The trial court did not permit him to challenge the search warrant because he had not established a sufficient interest in either the premises searched, since he was merely a guest, or the property seized, since he had disclaimed ownership. The Supreme Court followed the trial court $^{16}$ in rejecting the contention that evidence seized in violation of one person's fourth amendment rights can never be admitted against another person, ${ }^{17}$ but held that Jones had shown a sufficient personal interest in the premises and property to complain of the search.

The Supreme Court's insistence on a personal interest ${ }^{18}$ reaffirmed

13362 U.S. 257 (1960).

14 Three other cases which raised the standing issue were disposed of without extended analysis of the problem. Wong Sun v. United States, 371 U.S. 471 (1963); United States v. Jeffers, 342 U.S. 48 (1951); McDonald v. United States, 335 U.S. 451 (1948). In McDonald the Court permitted a defendant to suppress evidence obtained in violation of his codefendant's rights by noting that had the evidence been properly returned to the codefendant it would not have been available for use at the defendant's trial. But the Court chose not to elaborate on the source or scope of the standing requirement. The importance of the case for the present discussion is further limited by the probability that it was overruled by Wong Sun. See note 26 infra.

15 Record, pp. 59-62, Jones v. United States, 362 U.S. 257 (1960).

16 The Court of Appeals affirmed the trial court's ruling. Jones v. United States, 262 F.2d 234 (1958).

17362 U.S. at 263; see Brief for Petitioner, pp. 21-25.

18 The issue in Jones was actually presented in terms of statutory interpretation. Rule 41(e) of the Federal Rules of Criminal Procedure provides: "A person aggrieved by an unlawful search and seizure may move ... to suppress for use as evidence anything so obtained." The Court held that "person aggrieved" as used in the statute referred only to the victim of the search. As a matter of legislative intent, this is probably the proper view. See Comment, supra note 8,55 Mich. L. REv. at 580. Since the exclusionary rule 
the rule unanimously followed by the lower federal courts. ${ }^{19}$ However, while the lower courts had generally held that only a proprietary or possessory interest in either the premises searched or property seized would establish standing, ${ }^{20}$ Jones considerably liberalized the requirement by freeing it from such property law concepts. ${ }^{21}$ Thus, under Jones, "anyone legitimately on premises where a search occurs may challenge its legality by way of a motion to suppress when its fruits are proposed to be used against him." 22 And, at least in "cases where the indictment itself charges possession," 23 the defendant can challenge the

was expressly given constitutional status in Mapp $v$. Ohio, the Court has twice approved of the Jones holding. Ker v. California, 374 U.S. 23, 34 (1963); Wong Sun v. United States, 371 U.S. $471,492 \mathrm{n} .18$ (1963). The Jones interpretation of Rule 41(e) thus appears to be the prevailing constitutional test for standing. See Comment, supra note 8, 1965 WASH. U.L.Q. at 514-16.

19 Every circuit had such a requirement. See, e.g., Nunes v. United States, 28 F.2d 905 (1st Cir. 1928); United States v. Pepe, 247 F.2d 838 (2d Cir. 1957); Whitcombe v. United States, 90 F.2d 290 (3d Cir.), cert. denied, 302 U.S. 759 (1937); Grainger v. United States, 158 F.2d 236 (4th Cir. 1946); Parr v. United States, 255 F.2d 86 (5th Cir.), cert. denied, 358 U.S. 824 (1958); Gowling v. United States, 64 F.2d 796 (6th Cir. 1933); United States v. Eversole, 209 F.2d 766 (7th Cir. 1954); Schnitzer v. United States, 77 F.2d 233 (8th Cir. 1935); Kwong How v. United States, 71 F.2d 71 (9th Cir. 1934); Baskerville v. United States, 227 F.2d 454 (10th Gir. 1955); Accardo v. United States, 247 F.2d 568 (D.C. Cir.), cert. denied, 355 U.S. 898 (1957).

20 See generally Edwards, supra note 8.

21 "We do not lightly depart from this course of decisions by the lower courts. We are persuaded, however, that it is unnecessary and ill-advised to import into the law surrounding the constitutional right to be free from unreasonable searches and seizures subtle distinctions, developed and refined by the common law in evolving the body of private property law which, more than almost any other branch of law, has been shaped by distinctions whose validity is largely historical. . . . Distinctions such as those between 'lessee,' 'licensee,' 'invitee' and 'guest,' often only of gossamer strength, ought not to be determinative in fashioning procedures ultimately referable to constitutional safeguards." 362 U.S. at 266. See Note, The Exclusionary Rule and the Question of Standing, 50 GEo. L.J. 585, 593 (1962).

22362 U.S. at 267. This seemingly broad test has been given a niggardly interpretation by some of the state courts. See Carter v. State, 236 Md. 450, 204 A.2d 322 (1964) (passenger in automobile has no standing to object to search of the car); State v. Callaghan, 144 Mont. 401, 396 P.2d 821 (1964) (invitee cannot object to search of his host's home); State v. Keeling, 182 N.E.2d 60 (Ohio C.. C. P. 1962) (guests engaged with host in numbers operations cannot object because their presence in home was not for a legitimate purpose).

23962 U.S. at 264. Lower courts have split over the breadth to be given this exception. The statutes under which Jones was prosecuted did not make possession a crime per se but provided that proof of possession should be sufficient to convict unless the defendant could satisfactorily explain his possession. 21 U.S.C. § 174; 26 U.S.C. § 4704(a). The Court noted that it would not "allow the Government to deprive the defendant of standing to bring a motion to suppress by framing the indictment in general terms, while prosecuting for possession." 362 U.S. at 264-65. Compare State v. Konigsberg, 336 F.2d 844 (3d Cir. 1964) (exception applies only when possession is a crime per se), with People v. DeFilippis, 34 IIl. 2d 129, 214 N.E.2d 897 (1966) (exception applies whenever proof of possession is a necessary even if not sufficient element of the offense). See Comment, supra note 8, 1965 WASH. U.L.Q. at 492-506. 
search without asserting an interest in the property seized, since that admission would generally prejudice his substantive defense. ${ }^{24}$

Two years later, Wong Sun v. United States ${ }^{25}$ demonstrated that, despite the liberalization in Jones, the personal interest requirement for standing was still an important restriction on the exclusionary rule. Federal narcotics agents illegally arrested defendant Blackie Toy, who then directed the officers to the home of Johnny Yee, where they found narcotics which Yee said had been brought to him by Toy and defendant Wong Sun. The Supreme Court held that the evidence could not be admitted against Toy because it was the fruit of his unlawful arrest, but that it could be used against Wong Sun because he was not a victim of the officers' misconduct. ${ }^{26}$ Unfortunately, however, the Court, faced with a multitude of issues, chose not to elaborate on the reasons for the standing requirement. Accordingly, the Supreme Court's opinion in the Jones case remains the basic text for an inquiry into the doctrinal foundation of the present rule.

Mr. Justice Frankfurter's opinion in Jones, subscribed to by all nine members of the Court, ${ }^{27}$ opened by invoking "the general principle

24 Counsel for Jones suggested two reasons for permitting the defendant to challenge a search without admitting an interest in the items seized. First, the defendant's exercise of his fourth amendment rights should not be conditioned upon an admission of the crime of possession, a waiver of his fifth amendment privilege against self-incrimination. Second, even if forcing the defendant to choose between the two amendments is permissible, allowing the Government to win on contradictory assertions would breed disrespect for the legal system. Brief for Petitioner, pp. 32-44. The Court accepted the second rationale without mentioning the self-incrimination point. 362 U.S. at 263-64.

25371 U.S. 471, 492 (1963).

26 Ibid. It should be noted that Toy and Wong were co-defendants. Wong Sun would thus appear to have overruled McDonald $v$. United States, see note 14 supra, insofar as that case rested on the prejudicial effect of admitting evidence against one defendant at a joint trial and excluding it as to another. The cases can be distinguished in that the property seized in Wong Sun was contraband which the victim could not demand to have returned. But if the victim's right to compel the return of his property is the reason for excluding it as evidence against another person, there seems to be no reason to limit it to the situation in which the victim is a co-defendant. Under this logic, only seizures of contraband and stolen goods (property in which the victim does not have a lawful ownership interest) would be subject to the standing restriction, and most contraband cases would be covered by the "contradictory assertions" rule of Jones. See text accompanying note 24 supra. The "legitimately on the premises" test of Jones would have relevance only for seizures of stolen goods and for comparatively rare cases such as Wong Sun in which seized contraband was linked to the defendant in some manner other than possession. It is probably incorrect to attribute such arbitrary classification to the Court. The better guess is that Wong Sun overruled McDonald, even though the latter case was never cited. In view of the circumstance that standing was only one of many complex issues in the case-although the determinative one as far as defendant Wong Sun was concerned-this is perhaps understandable. See generally Broeder, supra note 8.

27 Mr. Justice Douglas joined the Court's opinion on the standing issue but dissented on the issue of probable cause. 
that a party will not be heard to claim a constitutional protection unless he "belongs to the class for whose sake the constitutional protection is given." "It then observed that criminal defendants as a class cannot qualify because evidence obtained by unreasonable searches and seizures is not "inherently unreliable or prejudicial." Rather, the exclusionary rule is "a means for making effective the protection of privacy." As such, Mr. Justice Frankfurter concluded, it exists only for the benefit of search victims. The last step is a large one. Within its cryptic logic must be found the rationale for the present standing requirement.

Given that the purpose of the exclusionary rule is the "protection of privacy," the next question is, "whose privacy?" The Jones answer to this is clear: the privacy of the victim of the illegal search. But it is difficult to see how the exclusionary rule accomplishes this objective. An unreasonable search can never be undone. At the time of exclusion, the victim's home has already been entered and his secrets have been uncovered. ${ }^{28}$ The only protection the exclusionary rule can give this type of privacy rests in the possibility that the police will be deterred from making a second search of the victim's premises. This "personal deterrence" rationale labors under several difficulties. For one, it has never been articulated. Adherents to the deterrence rationale for the exclusionary rule have always set their sights higher-the protection of all society's privacy, ${ }^{29}$ a notion at odds with the Jones conclusion that the search victim is the sole object of concern. Furthermore, the personal deterrence rationale aggravates the primary objection to the exclusionary rule, the feeling that the remedy is disproportionate to the problem: "the criminal is to go free because the constable has blundered." 30 It is perhaps possible to justify suppressing highly competent evidence under a "general deterrence" theory in the hope that future searches at other times and places will be deterred. But if the only concern is with the possibility of a second search of the same victim's premises, which is what the personal deterrence rationale states, then surely the argument for disproportion is impressive.

The Court's logic becomes convincing if a second approach to the concept of privacy is adopted. It is one thing for the police to intrude upon a person's domestic tranquility and uncover his secrets; it is quite another thing to send him to prison on the basis of what is found.

28 Linkletter v. Walker, 381 U.S. 618, 637 (1965).

29 See Kamisar, Wolf and Lustig Ten Years Later: Illegal State Evidence in State and Federal Courts, 43 MrN. L. Rev. 1083, 1145-47 (1959), and authorities cited.

30 People v. Defore, 242 N.Y. 13, 21, 150 N.E. 585, 587 (1926) (Cardozo, J.); 8 Wigmore, EVIDENCE § 2184, at 37 (3d ed. 1940); Allen, Federalism and the Fourth Amendment: $A$ Requiem for Wolf, 1961 Sup. CT. REv. 1, 36-37. 
The exclusionary rule does effectively protect against this second, and infinitely more serious, invasion of the victim's privacy. And limiting the benefit of the rule to search victims makes sense because the evil to be remedied is the combination of intrusion plus incrimination, not incrimination alone. This outlook often takes the form of justifying the exclusionary rule as the result of an interplay between the fourth and fifth amendments whereby the admission of evidence unconstitutionally seized from the defendant violates his fifth amendment right that "no person ... shall be compelled in any criminal case to be a witness against himself." 31 It is also consistent with a straight fourth amendment theory if one accepts the notion that the fourth amendment has a special concern with searches for evidence that will incriminate the victim ${ }^{32}$ such that a special remedy for this evil, the exclusionary rule, is to be found within the amendment "by judicial implication." ${ }_{3}$ The distinction between these two viewpoints is formal only, a matter of constitutional elegance having no bearing on analysis of the standing problem. ${ }^{34}$ Each is an expression of a "personal incrimination"35 notion of the exclusionary rule. Each strongly supports the Court's reasoning in Jones.

If strict "logic" is to be the key, it seems fair to conclude then that the standing requirement as laid down in Jones and applied in Wong Sun is an outgrowth of the personal incrimination theory of the exclusionary rule rather than the personal deterrence or general deterrence theories. But it is hazardous to rely too heavily on abstract logic in interpreting the Court's intentions, particularly when the problem is of such practical importance and when the logic is to be found only by reading between the lines of a single opinion. It is necessary to examine the adversary and historical context within which the Jones

31 See, e.g., Ker v. California, 374 U.S. 23, 30 (1963); Mapp v. Ohio, 367 U.S. 643, 657 (1961); Zap v. United States, 328 U.S. 624, 628 (1946); Davis v. United States, 328 U.S. 582, 587 (1946); Olmstead v. United States, 277 U.S. 438, 462 (1928); Agnello v. United States, 269 U.S. 20, 33-34 (1925); Amos v. United States, 255 U.S. 313, 316 (1921); Gouled v. United States, 255 U.S. 298, 306 (1921); Boyd v. United States, 116 U.S. 616, 630 (1886).

32 See Frank v. Maryland, 359 U.S. 360,365 (1959).

33 Wolf v. Colorado, 338 U.S. 25, 28 (1949).

34 While the distinction is of no importance in assessing the theoretical justification for the standing requirement, it is important in determining whether the Supreme Court is still operating under the personal incrimination rationale. Thus, an abandonment of the rationale based on the interplay of the fourth and fifth amendments would not necessarily mean an abandonment of the personal incrimination theory, as a straight fourth amendment rationale could still be operative.

35 The phrase "personal incrimination" is employed throughout this comment to describe the rationale, rather than the usual "self-incrimination," in order to emphasize the point that the rationale does not depend on the interplay with the fifth amendment but can survive under either a straight fourth amendment or a fourth-fifth analysis. 
case was decided before determining under which theory its present-day validity should be assessed.

Counsel for Jones, in contending that there should be no requirement of standing as a prerequisite for the invocation of the exclusionary rule, suggested two rationales: (1) general deterrence; and (2) the protection of judicial integrity which would be defeated were the courts to participate in official lawlessness by accepting the evidence so obtained. ${ }^{\text {Bb }}$ Mr. Justice Frankfurter's unequivocal assertion that the exclusionary rule "is a means for making effective the protection of privacy" together with his approval of the general notion of a standing requirement in the search and seizure area would seem to be a rejection of the judicial integrity rationale, which really cannot coexist with any form of a standing requirement.

Petitioner's general deterrence argument was never answered, either in the government's brief or the Court's opinion. The government instead contended that, whatever the mechanics of deterrence, previous decisions had established that the "right is a personal right, which each individual enjoys in respect of his own person, dwellingplace, papers and effects, and which, like other personal rights and privileges, he may waive." 37 The three cases cited in support of this propositionDavis v. United States, ${ }^{38}$ Zap v. United States, ${ }^{30}$ and Amos v. United States ${ }^{40}$-each contain an explicit adoption of the personal incrimination theory of the exclusionary rule. ${ }^{41}$ While the Court in ruling for the government on this issue did not expressly adopt its contentions, it is probably more accurate to interpret the Court's silence as an implicit acceptance of the government's reasoning rather than as a $s u b$ silentio adoption of the petitioner's general deterrence argument coupled with a policy determination that the desirable quantity of deterrence could be achieved without completely abandoning the

36 Brief for Petitioner, pp. 21-25.

37 Brief for the United States, p. 22.

38328 U.S. 582 (1946).

30328 U.S. 624 (1946).

40255 U.S. 318 (1921).

41328 U.S. at 628; 328 U.S. at 587; 255 U.S. at 316. In each case the adoption was in the form of the fourth-fifth rationale. The statement in Davis is typical: "The law of searches and seizures as revealed in the decisions of this Court is the product of the interplay of these two constitutional provisions. Boyd $v$. United States, 116 U.S. 616. It reflects a dual purpose-protection of the privacy of the individual, his right to be let alone; protection of the individual against compulsory production of evidence to be used against him." 328 U.S. at 587. The conceptual identity between the two forms of the personal incrimination theory can be ascertained by comparing the above statement of the fourthfifth rationale with the statement of the straight fourth amendment personal incrimination rationale contained in Frank v. Maryland. See text accompanying note 47 infra. 
standing requirement. ${ }^{42}$ Thus, what little light the adversary context sheds on the problem also points toward the conclusion that the Jones opinion was based on the personal incrimination theory of the exclusionary rule.

An analysis of the historical context of the Jones decision yields similar results: ambiguity generally with the personal incrimination theory emerging as the most likely basis for the Court's application of the exclusionary rule. Until 1949 the personal incrimination theory, in the form of an explicit acknowledgment of an interplay between the fourth and fifth amendments, was the accepted rationale for the exclusionary rule in the federal court system. ${ }^{43}$ The Court's opinion in Wolf $v$. Colorado, ${ }^{44}$ holding that the rule did not apply to the states through the fourteenth amendment, introduced some ambiguity as to the role of the privilege against self-incrimination by speaking solely in terms of the efficacy of various deterrent mechanisms. ${ }^{45}$ The 1950 's did little to clarify the issue as state searches were judged by general due process standards rather than the specifics of the fourth and fifth amendments. ${ }^{46}$ But in Frank $v$. Maryland, ${ }^{47}$ which was the last major

42 This conclusion is buttressed by the observation that quantity gradations of deterrence may be impossible to achieve in the. search and seizure situation. See text accom. panying notes 77-79 infra.

43 The Supreme Court first commented upon the interaction of the two amendments in Boyd v. United States, 116 U.S. 616, 630 (1886), a case involving the compulsory production of private papers. The opinion analogized a court order for production to an unreasonable search and concluded: "Breaking into a house and opening boxes and drawers are circumstances of aggravation; but any forcible and compulsory extortion of a man's own testimony or of his private papers to be used as evidence to convict him of crime or to forfeit his goods, is within the condemnation of that judgment. In this regard the Fourth and Fifth Amendments run almost into each other." Support for this observation was found in Lord Camden's landmark opinion in Entick v. Carrington, 19 Howell's State Trials 1029 (1765).

When the exclusionary rule was adopted for the federal system in Weeks v. United States, 232 U.S. 383 (1914), the Boyd reasoning was applied to the inverse situation: a garden variety fourth amendment violation was found to entail a fifth amendment problem when the evidence obtained was sought to be used in court. From Weeks to Wolf the Court routinely expounded the fourth-fifth rationale. See, e.g., Zap v. United States, 328 U.S. 624, 628 (1946); Agnello v. United States, 269 U.S. 20, 33-34 (1925); Gouled v. United States, 255 U.S. 298, 306 (1921). Even in cases in which the Court was divided, the dissenters never challenged the majorities' fourth-fifth framework for analysis. See, e.g., Davis v. United States, 328 U.S. 582, 587, 606-9 (1946) (Frankfurter, J.); Olmstead v. United States, 277 U.S. 438, 462, 477-79 (1928) (Brandeis, J.).

44338 U.S. 25 (1949).

$45 \mathrm{Mr}$. Justice Rutledge alluded to the fourth-fifth theory in dissent although he did not make an issue of it. $I d$. at 48 .

46 Breithaupt v. Abram, 352 U.S. 432 (1957); Irvine v. California, 347 U.S. 128 (1954); Rochin v. California, 342 U.S. 165 (1952). The cases developed a rule whereby if the police activity sufficiently "shocks the conscience" the fourteenth amendment does require that the states exclude the evidence, an approach reflecting a theme of fairness to the victim 
search and seizure case to be decided before Jones, the Court forcefully returned to the personal incrimination theory in holding that administrative searches are to be judged by more lenient standards of reasonableness than searches for incriminating evidence. Mr. Justice Frankfurter traced the history of the constitutional protection against unreasonable searches and seizures and concluded:

Against this background two protections emerge from the broad constitutional proscription of official invasion. The first of these is the right to be secure from intrusion into personal privacy, the right to shut the door on officials of the state unless their entry is under proper authority of law. The second, and intimately related protection, is self-protection: the right to resist unauthorized entry which has as its design the securing of information to fortify the coercive power of the state against the individual, information which may be used to effect a further deprivation of life or liberty or property. ... Certainly it is not necessary to accept any particular theory of the interrelationship of the Fourth and Fifth Amendments to realize what history makes plain, that it was on the issue of the right to be secure from searches for evidence to be used in criminal prosecutions or for forfeitures that the great battle for fundamental liberty was fought. ${ }^{48}$

Then came Jones. ${ }^{49}$ A year later, ${ }^{50}$ the return to the personal incrimination theory took the form of an explicit discussion of the interplay between the fourth and fifth amendments. Mapp $v$. Ohio ${ }^{51}$ overruled Wolf and held that the exclusionary rule applies to the states through the fourteenth amendment. The opinion ranged widely, at times even utilizing a general deterrence analysis, but it summarized as follows:

We find that, as to the Federal Government, the Fourth and

rather than deterrence since the test is so subjective as to be highly unpredictable and therefore inadequate as a standard to control police behavior.

47359 U.S. 360 (1959).

48 Id. at 365 .

49 See also Abel v. United States, 362 U.S. 217 (1960), decided the same day as Jones and employing a more lenient standard for judging the constitutionality of administrative arrest proceedings than is used for testing arrests by prosecutorial authorities. This would seem to be a reaffirmation of the principle discussed in Frank.

50 Three months after Jones, the Court in Elkins v. United States, 364 U.S. 206 (1960), abolished the silver-platter doctrine under which evidence unlawfully seized by state officials without participation by federal officials had been admitted in the federal courts. Although the opinion often referred to deterrence, the refusal to treat searches differently on the basis of the types of officials to be controlled marked a further return to emphasis on the victim of the search: "To the victim it matters not whether his constitutional right has been invaded by a federal agent or by a state officer." Id. at 215 .

51367 U.S. 643 (1961). 
Fifth Amendments and, as to the States, the freedom from unconscionable invasions of privacy and the freedom from convictions based upon coerced confessions do enjoy an "intimate relation" in their perpetuation of "principles of humanity and civil liberty (secured) ... only after years of struggle." ... They express "supplementing phases of the same constitutional purpose-to maintain inviolate large areas of personal privacy." .. The philosophy of each Amendment and of each freedom is complementary to, although not dependent upon, that of the other in its sphere of influence-the very least that together they assure in either sphere is that no man is to be convicted on unconstitutional evidence. ${ }^{52}$

Discussions of the Mapp case in two later majority opinions, Ker $v$. California ${ }^{53}$ and Malloy $v$. Hogan ${ }^{54}$ confirm the observation that the Court was operating under a personal incrimination rationale for the exclusionary rule at the time the Jones and Wong Sun cases were decided.

Thus, while it is hazardous to ascribe a uniform rationale to the Court's actions in the fluctuating search and seizure field, especially since the larger issue of federalism has played such an important role in recent years ${ }^{55}$ an examination of the adversary and historical contexts of the Jones case serves to support the conclusion that an inquiry into the present-day validity of the standing requirement must begin with an assessment of the vitality of the personal incrimination theory.

\section{The Foundation Removed: The Standing Doctrine and The Deterrence Rationale}

In Linkletter $v$. Walker ${ }^{56}$ the Court abandoned the personal incrimination theory and accepted a general deterrence rationale, pointing out that the real persons the exclusionary rule seeks to protect are the

52367 U.S. at 656-57. Mr. Justice Black joined the opinion of the Court, and chose also to supplement it with an historical discussion of the interplay between the fourth and fifth amendments. He clearly viewed the Mapp opinion as a return to the fourth-fifth rationale, and the majority opinion made no effort to disavow that point of view.

53 374 U.S. 23, 30 (1963).

54378 U.S. 1, 8 (1964). The Court supported its conclusion that the privilege against self-incrimination applies to the states with the following interpretation of Mapp: “Mapp held that the Fifth Amendment privilege against self-incrimation implemented the Fourth Amendment in such cases, and that the two guarantees of personal security conjoined in the Fourteenth Amendment to make the exclusionary rule obligatory upon the States." Ibid.

55 See generally Allen, Federalism and the Fourth Amendment: A Requiem for Wolf, 1961 Sup. CT. Rev. 1.

56381 U.S. 618 (1965). 
unknown potential victims of unreasonable police conduct. The petitioner was convicted in 1959 on the basis of evidence obtained by an unreasonable search and seizure. At the time of his trial Louisiana had not adopted the exclusionary rule and the fourteenth amendment did not require it. After Mapp applied the rule to the states in 1961, Linkletter brought a habeas corpus petition requesting that the decision be given retrospective effect. He argued that the exclusionary rule is not a general deterrent device but rather a personal right guaranteeing to the individual victim of the search that he not be convicted on the basis of unconstitutional evidence. The foundation for this contention, as presented in the petitioner's brief, was the reliance placed in Mapp on the personal incrimination theory. ${ }^{57}$ But the Court reinterpreted the meaning of the Mapp opinion and concluded that "in rejecting the Wolf doctrine as to the exclusionary rule [that the rule does not apply to the states] the purpose was to deter the lawless action of the police and to effectively enforce the Fourth Amendment. That purpose will not at this late date be served by the wholesale release of the guilty victims." "s8

Linkletter should be read cautiously, however, as its interpretation of exclusionary rule theory was undertaken in the shadow of the larger issue of retroactivity. The Court was clearly concerned with the problems of a wholesale jail release of search and seizure victims, ${ }^{\text {,8 }}$ and also with developing a theory of retroactivity that would serve in cases involving other constitutional rights. ${ }^{60}$ Yet it is significant that the Court chose to expound on the exclusionary rule in rather unguarded terms: "The misconduct of the police prior to Mapp has already occurred and will not be corrected by releasing the prisoners involved. . . . the ruptured privacy of the victims' homes and effects cannot be restored. Reparation comes too late." 61 If release of the victims is considered inadequate "reparation" for pre-Mapp searches, it would seem that it is similarly inadequate for post-Mapp searches. It thus appears that the Court has categorically rejected any form of reparation or personal incrimination analysis in favor of a straight general deterrence rationale. ${ }^{62}$ The Court's sweeping language cannot

57 Brief for Petitioner, pp. 14-16, Linkletter v. Walker, 381 U.S. 618 (1965).

58381 U.S. at 637.

59 Ibid.

60 The general theory of retroactivity laid down in the case has generated a spirited academic dialogue. Compare Mishkin, Foreword: The High Court, The Great Writ and the Due Process of Time and Law, 79 HARv. L. REv. 56 (1965), with Schwartz, Retroactivity, Reliability, and Due Process: A Reply to Professor Mishkin, 33 U. CHr. L. Rev. 719 (1966). 61381 U.S. at 637.

62 Insofar as the Court's previous adherence to the personal incrimination theory was 
be dismissed as inadvertent dictum, for it drew the direct fire of $\mathrm{Mr}$. Justice Black's scathing dissent:

The inference I gather from these repeated statements [in the majority opinion adopting the deterrence rationale] is that the rule is not a right or privilege accorded to defendants charged with crime but is a sort of punishment against offcers in order to keep them from depriving people of their constitutional rights. In passing I would say that if that is the sole purpose, reason, object and effect of the rule, the Court's action in adopting it sounds more like law-making than construing the Constitution. ... Quite aside from that aspect, however, the undoubted implication of today's opinion that the rule is not a safeguard for defendants but is a mere punishing rod to be applied to law enforcement officers is a rather startling departure from many past opinions, and even from $M a p p$ itself. ${ }^{63}$

The Court's language in Linkletter is all the more telling when it is noted that the general test for retroactivity set out in the casea balancing of (1) whether the purpose of the new rule would be forwarded by retroactive application; (2) how much reliance had been placed on the old rule; and (3) how a retroactive application would affect the administration of justice ${ }^{64}$-is sufficiently flexible to have allowed the Court to reach its desired result without ascribing a deterrence purpose to the exclusionary rule. The Court could have found that although the exclusionary rule is based on personal incrimination, the advancement of purpose incident to retroactive application would

based on the fourth-fifth rationale, the abandonment in Linkletter removed several troubling logical inconsistencies. Evidence can always be "compelled" from a defendant by means of a valid search warrant; if the exclusionary rule were truly an aspect of the privilege against self-incrimination, under no conditions could the police force the defendant to give up the evidence. Also, the Court's treatment of corporations is inconsistent with a fifth amendment rationale. It is well settled that a corporation is not protected by the self-incrimination privilege, yet corporations are given the benefit of the exclusionary rule regarding searches and seizures. Compare Hale v. Henkel, 201 U.S. 43 (1906), with Silverthorne Lumber Co. v. United States, 251 U.S. 385 (1920). Finally, the privilege has been thought to apply only to "evidence of a testimonial or communicative nature" and not to the physical evidence frequently involved in search and seizure cases, a view recently approved by the Supreme Court. Schmerber v. California, 384 U.S. 757, 761 (1966). See generally Kamisar, Wolf and Lustig Ten Years Later: Illegal State Evidence in State and Federal Courts, 43 MINN. L. Rev. 1083, 1088 n.16 (1959). These logical difficulties, of course, do not apply to the straight fourth amendment rationale for the personal incrimination theory. See text accompanying notes $32-33 \& 48$ supra.

63381 U.S. at 649.

64381 U.S. at 636. 
be outweighed by the disruptive effects on the system; ${ }^{65}$ or alternatively, that the purpose of the rule under the personal incrimination rationale would not be advanced by retroactive application. ${ }^{68}$ Instead, the Court made a sweeping commitment to the general deterrence theory.

The commitment is further evidenced by Tehan $v$. United States ex rel Shott ${ }^{07}$ a subsequent case dealing with the retroactivity of the application of the self-incrimination privilege to the states. Deterrence was characterized as the "single and distinct" purpose of the exclusionary rule, a particularly significant statement since the result reached by the Court-that the privilege is not retroactive-would have been strongly supported by a showing that Linkletter also involved personal incrimination. ${ }^{68}$

A troubling aspect of the Court's abandonment of the personal incrimination theory in Linkletter and Shott is that the relationship between the fourth and fifth amendments was never discussed, even to the extent of denying the existence of an interplay. This problm was remedied to a limited extent in the recent case of Schmerber $v$. California, ${ }^{69}$ which held that the taking of a blood sample over objection from a defendant accused of drunken driving did not in the particular circumstances of the case violate any of the defendant's constitutional rights. The Court scrupulously separated the defendant's contentions based on the fourth and fifth amendments, ${ }^{70}$ discussing them under separate headings and making clear the different scopes of the two provisions: "But if compulsory administration of a blood test does not implicate the Fifth Amendment, it plainly involves the broadly conceived reach of a search and seizure under the Fourth Amend-

65 Compare the approach taken by the Court to the problem of the retroactivity of the new confession rules. Johnson v. New Jersey, 384 U.S. 719, 735 (1966).

66 The tenuous reasoning of Tehan v. United States ex rel. Shott, 382 U.S. 406 (1966), which found that the "purpose" of the privilege against self-incrimination and the rule prohibiting comment on the defendant's failure to take the stand would not be advanced by retroactive application, could have been utilized to support this result. This is not to imply approval of that reasoning, it is only to suggest that the Court's refusal to invoke it in Linkletter coupled with its willingness to use it in Shott indicates that the abandonment of the personal incrimination approach in Linkletter cannot be explained away as based on a felt necessity to reach the desired result of non-retroactivity.

67382 U.S. 406 (1966).

68 Compare this refusal to employ the fourth-fifth analysis in order to support a fifth amendment result with the Court's earlier willingness to use just such a tactic in Malloy $v$. Hogan. See note 54 supra.

69384 U.S. 757 (1966).

70 Compare with the "shock-the-conscience" framework of analysis applied to a similar factual situation in the earlier case of Breithaupt v. Abram, 352 U.S. 432 (1957). See note 46 supra. 
ment." "71 This approach would seem to indicate that whatever interplay the Court may previously have seen between the fourth and fifth amendments has now been disavowed. ${ }^{72}$

Linkletter and its progeny add up to the conclusion that the Court is now operating under a general deterrence theory of the exclusionary rule. Since the Jones-Wong Sun standing doctrine has never been examined under this theory, a reappraisal of its current validity is in order.

The assumption of the deterrence theory is that by removing the basic incentive for unreasonable searches-the hope that they will turn up evidence helpful in obtaining convictions ${ }^{73}$ - the police will refrain from undertaking them ${ }^{74}$ and all citizens can rest more "secure in their persons, houses, papers, and effects." 75 This effect is achieved at the high cost of suppressing relevant evidence, but the judgment has long since been made that the price is worth it, for the command of the fourth amendment, apart from any consideration of the exclusionary rule, is that the proscribed searches not take place and if this command is fully obeyed the evidence is just as unavailable to society as when the amendment is flouted and the evidence is later suppressed

71384 U.S. at 767. The Court avoided any mention of an interplay between the two amendments, confining itself to the indisputable observation that the values protected by the two amendments "substantially overlap."

72 Of course, the abandonment of the fourth-fifth theory does not necessarily mean an abandonment of the personal incrimination theory. The straight fourth amendment rationale still remains. See text accompanying notes $32-33$ \& 48 supra. However, since all recent cases have utilized the general deterrence analysis and since the fourth amendment personal incrimination theory has not been mentioned since Frank v. Maryland in 1959, the abandonment of the fourth-fifth theory probably did sound the death knell for the entire personal incrimination approach.

73 This assumption may not sufficiently take into account another possible motive for unreasonable police conduct. The "harrassment search" is thought to be a frequently employed tactic, particularly for the typical "vice-squad" crimes such as gambling, prostitution, bootlegging, and narcotics in which there is no victim to aid in reporting the crime and identifying the offenders. See Allen, Federalism and the Fourth Amendment: A Requiem for Wolf, 1961 Sur. CT. REv. 1, 37-38.

74 This conclusion has been frequently challenged. The classic statement of the opposing view is contained in Mr. Justice Jackson's opinion in Irvine v. California, 347 U.S. 128, 136-37 (1954): "That the rule of exclusion and reversal results in the escape of guilty persons is more capable of demonstration than that it deters invasions of right by the police. The case is made, so far as the police are concerned, when they announce that they have arrested their man. Rejection of the evidence does nothing to punish the wrongdoing official, while it may, and likely will, release the wrong-doing defendant. It deprives society of its remedy against one lawbreaker because he has been pursued by another. It protects one against whom incriminating evidence is discovered, but does nothing to protect innocent persons who are the victims of illegal but fruitless searches. The disciplinary or educational effect of the court's releasing the defendant for police misbehavior is so indirect as to be no more than a mild deterrent at best."

75 U.S. Const. amend. IV. 
in court. It has been suggested, however, that the cost to society can be minimized by a selective application of the exclusionary rule and that limiting the right to suppress to the victims of the searches is a logical place to draw the line. ${ }^{76} \mathrm{But}$ an examination of the mechanics of deterrence in this area reveals that the problem is particularly unsuited to the concept of selective enforcement.

Unlike many deterrent mechanisms the exclusionary rule does not achieve its effect by the infliction of sanctions, ${ }^{77}$ but rather by the removal of incentives. The rule encourages police to refrain from unreasonable searches not for fear of punishment, ${ }^{78}$ but simply because there is no reason for making them. ${ }^{79}$ When the courts allow some violations of the fourth amendment to reap rewards, the removal of incentives, which is the only basis of the deterrence, is undermined. Even if the odds of a particular search turning up evidence against a non-victim are only one in ten, the nothing-to-lose-and-everything-togain philosophy is likely to dictate police behavior.

Moreover, the exclusionary rule has an educational function. It is intended to instill in police officers an appreciation of the importance of individual privacy, and in citizens a sense of respect for the integrity of the law enforcement system and, consequently, for the laws of the society. ${ }^{80}$ When selective violations of the Constitution are sanctioned by the courts, this mutual respect can only break down.

Finally, even if these objections are put to one side and the ignominy to police officers of having their evidence suppressed is considered a

70 Comment, Standing to Suppress Evidence Obtained by Unconstitutional Search and Seizure, 55 Mich. L. Rev. 567, 581 (1957).

77 After suppression the prosecution is left no worse off than it was before the search. It can still use whatever legitimate sources it may have had to obtain the same evidence: "The essence of a provision forbidding the acquisition of evidence in a certain way is not merely that evidence so acquired shall not be used before the Court but that it shall not be used at all. Of course this does not mean that the facts thus obtained become sacred and inaccessible. If knowledge of them is gained from an independent source they may be proved like any others, but the knowledge gained by the Government's own wrong cannot be used by it in the way proposed." Silverthorne Lumber Co. v. United States, 251 U.S. 385, 392 (1920), cited with approval in Wong Sun v. United States, 371 U.S. 471, 485 (1963).

78 It may be that police offcers refrain from making unreasonable searches for fear of internal sanctions, public opinion repercussions, or tort suits. But the assumption of the exclusionary rule under current thought is that these devices are inadequate as deterrents. Mapp v. Ohio, 367 U.S. 643, 651-52 (1961).

79 Elkins v. United States, 364 U.S. 206, 217 (1960).

80 "Our Government is the potent, the omnipresent teacher. For good or for ill, it teaches the whole people by its example. Crime is contagious. If the Government becomes a lawbreaker, it breeds contempt for law; it invites every man to become a law unto himself; it invites anarchy." Olmstead v. United States, 277 U.S. 438, 485 (1928) (Brandeis, J., dissenting). 
sanction, classification according to "victimness" does not seem to be a good formula. The efficacy of a system of selective enforcement depends on the unpredictability of the method of selection. Every would-be violator of the law must know that there is a chance that he will be punished. But in the Jones-Wong Sun class of cases, the police can often predict which searches will turn up evidence against persons other than the victim. A system of classification based on "victimness" provides no deterrence against these searches. It would be more effective from the standpoint of deterrence analysis to draw lots.

It is fair to conclude that the standing requirement is inconsistent with the presently accepted general deterrence theory of the exclusionary rule. Significantly, the only court to consider the issue in those terms has come to the same decision. California adopted the exclusionary rule on its own initiative in 1955 , relying on the deterrence theory. ${ }^{81}$ Shortly thereafter, the issue of standing came up in People v. Martin. ${ }^{82}$ The Supreme Court of California, speaking through Mr. Justice Traynor, acknowledged the precedents from the lower federal courts adopting the standing requirement but dismissed them as inapplicable because they were based on the personal incrimination theory. ${ }^{83}$ The court then analyzed the standing issue in the light of its own deterrence theory and concluded: "Since all the reasons that compelled us to adopt the exclusionary rule are applicable whenever evidence is obtained in violation of constitutional guarantees, such evidence is inadmissible whether or not it was obtained in violation of the particular defendant's constitutional rights." 84

Viewed within the context of a system of general deterrence, which is what current theory would have us believe the exclusionary rule is meant to achieve, the Jones-Wong Sun standing requirement is an anomaly. If the decision were solely one of policy, as it is insofar as the Supreme Court's supervisory power to set the rules of evidence in the federal court system is concerned, ${ }^{85}$ the standing requirement ought to be abandoned in favor of the California rule that the fruits of unreasonable searches and seizures can never be admitted in any criminal trial. But the Supreme Court has no power to set the rules of evidence for the state systems; its only control is achieved by means of enforcing those rights of the accused which are compelled by the Constitution. Therefore, it becomes necessary to determine whether a constitutional

81 People v. Gahan, 44 Cal. 2d 434, 282 P.2d 905 (1955).

8245 Cal. 2d 755, 290 P.2d 855 (1955).

$83 I d$. at $759-60,290$ P.2d at 857 .

$84 \mathrm{Id}$. at 761,290 P.2d at 857.

85 See Elkins v. United States, 364 U.S. 206, 216 (1960). 
basis can be found for the exclusion by a defendant of evidence obtained in violation of some other person's privacy.

\section{Rights, REMedies, AND Constitutional Restrictions on Who May Assert Them}

\section{A. Vicarious Assertion of Constitutional Rights}

In Jones the Court rested its decision partly on "the general principle that a party will not be heard to claim a constitutional protection unless he 'belongs to the class for whose sake the constitutional protection is given." "s8 Unless it can be shown that the general principle is not immutable or that non-victims belong to the class for whose sake the exclusionary rule operates, the tension between the personal interest standing requirement and the goal of general deterrence cannot justify a Supreme Court determination that the states must allow non-victims to invoke the exclusionary rule.

On many occasions the Supreme Court has refused to allow defendants or other adversaries to rely on the constitutional rights of others. ${ }^{87}$ Indeed, it can be argued that the provision of Article III limiting the judicial power of the United States to cases or controversies compels not only adversary parties and "ripe" issues, but also contentions based solely on personal rights. ${ }^{88}$ This interpretation has not prevailed with the Court, however, for in three important modern cases $^{89}$ defendants have been awarded judgment on the basis of the constitutional rights of third parties, and the general policy against such reliance has been declared a rule of practice rather than a constitutional mandate.

The leading case in this respect is Barrows $v$. Jackson, ${ }^{90}$ in which a white party to a restrictive covenant was allowed to assert the equal protection rights of Negro purchasers in defense of a breach of covenant action against him. The Court treated the issue of vicarious assertion

86362 U.S. 257, 261 (1960), quoting New York ex rel. Hatch v. Reardon, 204 U.S. 152, 160 (1907).

87 E.g., United States v. Raines, 362 U.S. 17 (1960); American Power \& Light Co. v. SEC, 329 U.S. 90 (1946); Blair v. United States, 250 U.S. 273 (1919); Yazoo \& M.V.R.R. v. Jackson Vinegar Co., 226 U.S. 217 (1912); New York ex rel. Hatch v. Reardon, 204 U.S. 152 (1907); Davis \& Farnum Mfg. Co. v. Los Angeles, 189 U.S. 207 (1903); cf. Tileston v. Ullman, 318 U.S. 44 (1943).

88 See Dowling \& Gunther, Casfs on Constitutional Law 97-98 (7th ed. 1965).

89 While the modern cases are most closely in point, the concept of vicarious assertion of constitutional rights is not of recent vintage. See Pierce v. Society of Sisters, 268 U.S. 510 (1925).

90346 U.S. 249 (1953). 
as one of policy ${ }^{91}$ and gave particular weight to the circumstance that "it would be difficult if not impossible for the persons whose rights are asserted to present their grievance before any court." 92 The Barrows approach was followed in NAAGP v. Alabama, ${ }^{93}$ in which it was held that a private association could invoke the rights of its members to freedom of speech and association in resisting an order to produce membership lists. Again, in Griswold v. Connecticut ${ }^{94}$ a doctor and a director of a planned parenthood league were permitted to defend against prosecution for violation of an anti-contraceptive statute on the basis of their patients' rights of privacy and association. The Court did not spell out a precise formula in these cases as to when vicarious assertion should be allowed, preferring, apparently, to let the matter be settled on a case by case basis so that the policy considerations can be weighed each time rather than be governed by generalizations. Apart from the unique policy considerations of each problem area, the cases seem to treat as a key factor the impracticability of assertion by the true possessor of the right..$^{95}$ Thus, the Negro purchasers in Barrows were not parties to the suit, and probably could not have been made parties. ${ }^{96}$ Were the association members in NAACP $v$. Alabama or the patients in Griswold to have come forward to claim their rights, the very privacy those rights were supposed to protect would have been defeated.97

91 "Under the peculiar circumstances of this case, we believe the reasons which underlie our rule denying standing to raise another's rights, which is only a rule of practice, are outweighed by the need to protect the fundamental rights which would be denied by permitting the damages action to be maintained." 346 U.S. at 257.

92 Id. at 257.

93 357 U.S. 449 (1958).

94381 U.S. 479 (1965).

95 The same conclusion is reached in Sedler, Standing to Assert Constitutional Jus Tertii in the Supreme Court, 71 YALE L.J. 599, 627-28 (1962). After an exhaustive sorting out of the many cases in the area, the author concludes "that there are four factors which the Court takes into account in determining the scope of standing to assert the rights of others-(1) the interest of the assailant, (2) the nature of the right asserted, (3) the relationship between the assailant and third parties, and (4) the practibility of assertion of such rights by third parties in an independent action - and that a decision to grant or to deny standing in a given case will depend on the relative presence or absence of the various factors." The practibility of assertion factor is termed "probably the most significant of the four factors." Professor Sedler believes that the application of his four factor formula to the search and seizure situation yields the conclusion that the standing requirement ought to be abolished and that defendants should always be allowed to assert the fourth amendment rights of others. Id. at 656-58. While it may be doubted whether the Sedler approach places sufficient emphasis on the uniqueness of the policy decision in each prob. lem area, and also whether it may not artificially proliferate the number of factors involved, the article's basic utilization of interest analysis and its thorough handling of the cases make it a helpful contribution.

96 Id. at 631.

97 "To require that it be claimed by the members themselves would result in nullif- 
Application of the Barrows approach to the search and seizure cases raises some new problems. It has been established that as a matter of general policy under the deterrence rationale, vicarious assertion would be desirable. The "impracticability of assertion" factor is satisfied by the conclusion in Mapp v. Ohio that "other remedies have been worthless and futile;" the Court is convinced that the search victim who is not prosecuted has no effective forum in which to vindicate his fourth amendment rights. ${ }^{98}$ But the fact that the true possessor of the right in the search and seizure area is specific and identifiable and that his testimony may be necessary to determine the reasonableness of the search raises the difficult question of waiver to a prominence not present in the other cases. The victim of the search may be indifferent as to the fate of the defendant and may be quite unwilling to reveal in open court that he was sufficiently under suspicion, and perhaps sufficiently associated with the defendant, to have been searched. He may prefer, instead, to waive his fourth amendment right.99 If the defendant is to be given standing under the Barrows line of cases as the vicarious representative of the victim, this right to suppress the evidence must be conditioned upon a decision by the victim to exercise the constitutional right, or, at the very least, subject to a decision by the victim not to invoke the right. In making this decision, the victim will be under heavy pressure, and in some cases coercion, from both the law enforcement authorities and the defendant. To combat this, a preliminary hearing on the question of waiver, to which the victim may be subpoened, should be required. The hearing should be in camera so as to protect the privacy of the victim who may wish to waive his right. The traditional presumption against the waiver of a constitutional right should be employed. ${ }^{100}$

If adequate provision is made for the possibility of waiver, there appears to be nothing to prevent the application of the established vicarious assertion concept to the search and seizure area. This approach will permit the Court to implement the general deterrence policy of the exclusionary rule, and still insure that the interests of the victim, who is the true possessor of the right, remain controlling.

cation of the right at the very moment of its assertion." NAACP v. Alabama, 357 U.S. 449,459 (1958). Compare the use of a fictitious name in order to protect the privacy of the patients in Poe v. Ullman, 367 U.S. 497 (1961), a case involving the same statute at issue in Griswold.

98367 U.S. 643, 651-53 (1961). See also Sedler, supra note 95, at 657. But see Foote, Tort Remedies for Police Violations of Individual Rights, 39 MINN. L. REv. 493 (1955).

99 This "waiver" is not to be confused with "consent" at the time of the search, which in effect makes it a reasonable search. The "waiver" problem arises after an admittedly unreasonable search has taken place.

100 Cf. Miranda v. Arizona, 384 U.S. 436, 475-76 (1966). 


\section{B. General Constitutional Rights Belonging to Every Citizen}

The possibility of waiver by the victim may undercut to some extent the "nothing-to-gain" basis for the general deterrence sought to be achieved by the exclusionary rule. ${ }^{101}$ The California rule, which permits defendants to suppress unreasonably seized evidence regardless of the wishes of the victims is not subject to that danger. It can be raised to constitutional status if non-victims can be considered to belong "to the class for whose sake the constitutional protection is given." Under a rather unconventional yet, in light of the deterrence rationale, perhaps realistic interpretation of the exclusionary rule, non-victims would qualify as within the protected class. In recent years the Court has recognized in other areas that some constitutional liberties are not really "personal" in nature in the sense that they are violated when governmental action has a given impact on specific individuals, but rather are "general" in nature in that they are violated the moment governmental action is taken regardless of the impact of that action on any ascertainable persons. "Citizens' rights"102 of this sort can be asserted by anyone having a genuine adversary interest in the proceedings since all citizens belong to the class for whose sake the right is given.

A line of decisions dealing with standing to invoke the establishment of religion clause of the first amendment indicates that the Court is now treating that as a general citizen's right. Taxpayers have challenged a municipal expenditure of funds for the bus transportation of parochial school students. ${ }^{103}$ Taxpayers with children in school have been given standing to invoke the establishment clause against released time practices, ${ }^{104}$ prayer recitation, ${ }^{105}$ and Bible reading in public

101 In reality it may turn out that the undermining of deterrence may not be as great as would be supposed. The possibility of a waiver by the victim could be remote-or at least remote enough as to not enter the minds of the police officers at the time of the decision whether or not to search. Also, the situations in which the police are likely to predict that evidence against a non-victim will be found-generally, investigations of organized rings-are the very situations in which a pre-existing relationship is likely to result in the victim being willing to appear in court to save the defendant. For a similar application of this de minimus incentive concept under a deterrence analysis, see Sandalow, Henry v. Mississippi and the Adequate State Ground: Proposals for a Revised Doctrine, 1965 Sup. CT. Rev. 187, 237.

102 The concept of "citizens' rights" as it relates to the standing issue generally is exhaustively treated in Jaffe, Standing to Secure Judicial Revietw: Public Actions, 74 Harv. L. REv. 1265 (1961).

103 Everson v. Bd. of Education, 330 U.S. 1 (1947).

104 Zorach v. Clauson, 343 U.S. 306 (1952); Illinois ex rel. McCollum v. Bd. of Education, 333 U.S. 203 (1948).

105 Engel v. Vitale, 370 U.S. 421 (1962). 
schools. ${ }^{106}$ Defendants charged with selling goods in violation of Sunday closing laws have been permitted to contend that the laws amounted to an establishment of religion without alleging their personal religious beliefs. ${ }^{107}$ In each case the impact of the governmental action on the person raising the constitutional challenge was not necessary to prove a violation of the first amendment; every citizen has a right that his government not establish a religion. ${ }^{108}$ The status of taxpayer or parent or defendant was necessary to satisfy minimal adversary interest requirements, not to prove inclusion in the protected class. ${ }^{109}$

When the wording of a statute ${ }^{110}$ or the judicial construction given a statute ${ }^{111}$ or the common law $w^{112}$ has an inhibiting effect upon free expression, one whose particular conduct could be constitutionally regulated may nonetheless challenge the law for overbreadth. Although such a challenge is often tied in with the due process concept of vagueness whereby a person may not be punished unless he had fair notice that his conduct was illegal, ${ }^{113}$ the Court on occasion has permitted

100 School District of Abington v. Schempp, 374 U.S. 203 (1963). For a critical analysis of the standing issue and the Court's rather cursory treatment of it in these cases, see Brown, Quis Custodiet Ipsos Custodes?-The School Prayer Cases, 1963 SuP. Cr. REv. I.

107 McGowan v. Maryland, 366 U.S. 420 (1961).

108 By way of contrast, the free exercise of religion clause of the first amendment is not such a citizen's right; it is violated only when governmental action has a specific impact-prohibition of free exercise-on a given individual. The McGowan case provides an ideal illustration of this. The defendants sought to challenge the statute, a Sunday closing law, under both the establishment and free exercise clauses. Standing was denied to assert the free exercise claim because the defendants' failure to disclose their religious beliefs precluded them from demonstrating a personal religious interest resulting from the government's impact on them. The personal religious interest was not required for the establishment clause claim; the economic injury alleged by the defendants was enough to give them adversary status, and that is all that is required for contentions based on citizens' rights. The Court justified its treatment of the establishment clause as a citizen's right, although it did not use the phrase, in the following terms: "If the purpose of the 'establishment' clause was only to insure protection for the 'free exercise' of religion, then what we have said above concerning appellants' standing to raise the 'free exercise' contention would appear to be true here. However, the writings of Madison, who was the First Amendment's architect, demonstrate that the establishment of a religion was equally feared because of its tendencies to political tyranny and subversion of civil authority." 366 U.S. at 430.

109 Thus, a taxpayer whose child was no longer in school was denied standing when the cost of the challenged practice could have no conceivable impact on his tax bill. Doremus v. Bd. of Education, 342 U.S. 429 (1952).

110 Dombrowski v. Pfister, 380 U.S. 479 (1965); Stromberg v. California, 283 U.S. 359 (1931).

111 Terminiello v. Chicago, 337 U.S. 1 (1949); Winters v. New York, 333 U.S. 507 (1948); Thornhill v. Alabama, 310 U.S. 88 (1940); Herndon v. Lowry, 301 U.S. 242 (1937). 112 AFL v. Swing, 312 U.S. 321 (1941).

113 The often confused concepts of overbreadth and vagueness are carefully distin- 
defendants whose conduct was constitutionally punishable and who had full notice that they were violating the law to challenge the rule solely because its broad sweep might deter others from engaging in activity that is constitutionally protected. ${ }^{114}$ The defendant is allowed to assert a general right, which he shares with all citizens, against such speechdeterring governmental action whether it be in the form of a statute or a common law rule. ${ }^{115}$ The fact that the overbreadth of the rule had no particular impact on his conduct is immaterial; the right belongs to all citizens ${ }^{116}$ and his defendant status makes him the appropriate adversary to assert it. ${ }^{117}$

Again, in the reapportionment cases ${ }^{118}$ citizens were allowed to contend that their state legislatures were not apportioned in conformity with the requirements of the equal protection clause even though they did not demonstrate that the alleged constitutional violation had any impact on themselves. ${ }^{119}$ Citizens in overrepresented districts may not have standing to challenge the apportionment, but this can be attributed to doubts about their adversary status rather than to a determination that the right does not belong to citizens in general.

Under conventional right-remedy analysis the applicability of the citizen's right concept to the exclusionary rule situation is doubtful.

guished in Bernard, Avoidance of Constitutional Issues in the United States Supreme Court: Liberties of the First Amendment, 50 Mich. L. REv. 261, 273-77 (1951). On the void-for-vagueness doctrine generally, see Amsterdam, The Void-for Vagueness Doctrine in the Supreme Court, 109 U. PA. L. REv. 67 (1960).

114 Winters v. New York, 393 U.S. 507 (1948); Stromberg v. California, 283 U.S. 359 (1931). In Dombrowski v. Pfister, 380 U.S. 479 (1965); Thornhill v. Alabama, 310 U.S. 88 (1940); and Herndon v. Lowry, 301 U.S. 242 (1937), the fair notice issue was debatable, but the Court chose to rely on overbreadth. Usually, in these cases the Court does not discuss whether the conduct in the record could constitutionally be punished, which indicates that the question is irrelevant when the law is being attacked on its face. See Sedler, supra note 95 , at 613 .

115 AFL v. Swing, 312 U.S. 321 (1941). Thus, the relevance of the overbreadth cases to the search and seizure situation is not diminished by the fact that the exclusionary rule as a constitutional requirement against the states is not codified.

116 It might be asserted that the true possessors of the right in these cases make up a category somewhat less inclusive than the general citizenry-those persons who may be deterred from speaking by the overbreadth of the rule. But this characteristic, framed as it is in terms of potential, really takes in all citizens. And insofar as the relevance of these cases to the search and seizure situation is concerned, the category consisting of all potential search victims is analytically identical.

117 Closely related is the line of cases in which convictions based on statutes or ordinances giving administrative officials too much discretion in regulating speech have been overturned without regard to the particular conduct involved in the case. See Cox v. Louisiana, 379 U.S. 549, 557-58 (1965); Kunz v. New York, 340 U.S. 290 (1951); Saia v. New York, 334 U.S. 558 (1948).

118 E.g., Reynolds v. Sims, 377 U.S. 533 (1964); Baker v. Carr, 369 U.S. 186 (1962).

119 See generally Neal, Baker v. Carr: Politics in Search of Law, 1962 Sup. CT. Rev. 252. 
Unlike the establishment clause, speech deterrence, and reapportionment cases, the search and seizure cases involve specific and identifiable victims of the governmental conduct. There is no constitutional violation until the police action has a certain impact on a specific individual -the invasion of his privacy. The general citizenry cannot be said to have a right against $A$ 's home being unreasonably searched; only $A$ has that right. Under conventional analysis of the exclusionary rule, evidence is excluded as a remedy for the violation of $A$ 's right. Others should perhaps be able to assert the right and invoke the remedy, but not as general citizens, only as vicarious representatives of $A .{ }^{120}$ Hence the citizen's right concept should not be applied.

The complete commitment to the deterrence rationale of the exclusionary rule, ${ }^{121}$ however, may call for a reexamination of the conventional analysis. If the persons who are really being protected by the suppression of the evidence are the unknown potential victims of police misconduct, it is difficult to see why their protection should be considered a remedy for the victim of the search. The personal remedy notion is a product of the personal incrimination rationale, a feeling that although the victim's privacy has already been invaded and can never be repaired, he still has a remedy against the more serious invasion of being sent to prison on the basis of what was found. The general deterrence rationale, on the other hand, implies that there are two separate rights contained in the fourth amendment: (1) the personal right to be free from unreasonable searches and seizures; and (2) the right of the general citizenry that unreasonably seized evidence not be used in court so that the police will be deterred from invading their privacy in the future. If this is true, the exclusionary rule is not a remedy but a right, a general citizen's right to have the police deterred, which can be asserted by all defendants because of their adversary status.

Thus, if it is agreed that the present standing requirement does not sit well with the general deterrence purpose of the exclusionary rule, the Supreme Court has available at least two doctrinal alternatives to justify as a matter of federal constitutional law the substantial elimination of the standing requirement in the state courts. Traditional analysis in terms of the vicarious assertion of constitutional rights can support the elimination of the standing requirement, subject only to the limitation that victims be permitted to waive their fourth amendment rights and prevent defendants from suppressing the evidence. Should 
the Court desire to eliminate even this undercutting of the "nothingto-gain" basis for deterrence, ${ }^{122}$ it could make a dramatic departure from conventional right-remedy analysis of the exclusionary rule and bring the rule within the citizen's right concept recognized in other areas of constitutional law. While such a departure could be supported under the present general deterrence theory of the exclusionary rule, it may be that the incremental deterrence at stake would not justify such a daring theoretical move.

\section{Conclusion: Weak Footing for Standing}

One of the implications of the Court's commitment to the general deterrence rationale for the exclusionary rule is that the present standing requirement is without a theoretical foundation. In addition, there are practical reasons for removing the standing requirement. The middle-of-the-road approach attempted in Jones and Wong Sun has resulted in a variable standard among the states and federal districts, and in a considerable amount of litigation over the standing issue. ${ }^{123}$ When it is considered that the Supreme Court in the search and seizure area is enforcing a constitutional provision that is highly controversial, it is not hard to appreciate the importance of a clear-cut rule which is easy to understand and apply and which makes difficult any attempt to defeat the substantive policy through artificial distinctions. Furthermore, when it is noted that the decision in Mapp v. Ohio was heralded because it would allow the Court to devote its full attention to the difficult task of defining the concepts of "unreasonable search" and "probable cause,"124 the efficacy of a rule which minimizes the amount of litigation over collateral issues should not be underestimated. Accordingly, if the Court chooses to persist in its general deterrence view of the exclusionary rule, a weighing of all considerations involved points to an abandonment of the personal interest requirement for standing.

122 See note 98 supra.

123 The cases are collected in Comment, Standing to Object to an Unlawful Search and Seizure, 1965 WASH. U.L.Q. 488 (1965).

124 Allen, Federalism and the Fourth Amendment: $A$ Requiem for Wolf, 1961 Sur. Cr. REV. 1, 48 . 